\title{
Findings in CSOM: Our Experience in Sudanese Population-A CT based Study
}

\author{
Zuhal Yassin Ali Hamd ${ }^{1},{ }^{*}$ Caroline Edward Ayad², \\ Mohamed. E. M. Gar-elnabi ${ }^{2}$ \\ ${ }^{1}$ National University-Khartoum-Sudan \\ ${ }^{2}$ Sudan University of Science and Technology-Khartoum-Sudan \\ Corresponding author: *Caroline Edward Ayad ${ }^{2}$
}

\begin{abstract}
Chronic suppurative otitis media (CSOM) is one of the leading causes of hearing impairment in developing countries. Objectives: are to highlight the high resolution computerized tomography (HRCT) temporal bone findings in chronic middle ear infections with reference to it s extent and complications, as well, the presented common signs, symptoms and the duration impact on the anatomical structures and pathological changes in each part and for both sides.

Materials and Methods: Preliminary clinical assessment was obtained for 114 patients diagnosed with CSOM, and then they were referred for a HRCT of temporal bone which was done using multi-detector CT scanner.

Results: Of the 114 patients; 63(55.3\%) were males and 51(44.7\%) were females: Otorrhoea is the most common symptom, and was found in 113 patients constituting (99.1\%) followed by Otolegia 69(60.5\%) and headache affected 53(46.5\%) of the cases. CSOM is more common in low socio-economic status .In ears affected with CSOM, the maximum CT number (Hounsfield) was found to be changed and was significantly affected with increasing patients' age. Sclerotic changes and soft tissue density increased as the duration of CSOM increased in right and left middle ears significantly $(F=5.802$, Sig at 0.000), and ( $F=23.182$, Sig at .015) respectively. Partial and complete erosion were detected in both right and left ossicle in the advanced phase of disease, where the ossicle still intact in the early stage, and the correlation is found to be significant with increasing of CSOM duration $(F=16.959$, Sig 0.000) and $(F=3.673$, Sig $=0.036)$ for right and left ossicles respectively. Changes including total and partial opacification, sclerotic changes, soft tissue density, mucosal thickening were the findings detected in both right and left mastoid in HRCT for temporal bone scanning.

Conclusions: HRCT of temporal bone is useful in identifying various findings related to the location and extent of disease.
\end{abstract}

Keywords - Computerized Tomography, Otitis media, Hearing loss

\section{INTRODUCTION}

Chronic suppurative otitis media (CSOM) is a major cause of acquired hearing impairment in children.[1] CSOM remains a significant health problem in terms of prevalence, economics and sequelae. It can be avoided if diagnosed early and properly treated. [2] Studies showed that CSOM affect millions of children around the world annually with attendant complications presented in more than half of the cases. [3,4].

Long duration lead to severity of the cases compared with acute otitis media. [5]The importance of taking care about CSOM in children because it is likely inhibits language and development. Several studies have linked persistent and significant hearing loss from otitis media during the first two years of life with learning disabilities [6,7]. Other studies have shown no effect. [8,9]

At a recent World Health Organization (WHO) meeting of experts from 15 African countries, CSOM was considered most common cause of persistent mild to moderate hearing problems in developing countries. [10] The disease and its sequelae produce financial and public costs. A prevalence of CSOM greater than $1 \%$ in children in a defined community indicates that there is an avoidable burden of the disease. A prevalence of $4 \%$ or greater indicates a public health problem that needs critical consideration. [11]The burden of CSOM varies. Global prevalence rates estimates a range between $1 \%$ and $46 \%$; it has been estimated that 65-330 million individuals have discharging ears, $60 \%$ of whom suffer from significant hearing impairment. [1]According to the WHO, Western Pacific countries have the highest prevalence, followed by South East Asia, Africa, South and Central America, the Eastern Mediterranean, and finally Europe. [12]

Imaging plays an important role in providing key information to the surgeon in this regard. Many imaging modalities are available for the evaluation of the temporal bone, including conventional radiographs, computed tomography (CT), and magnetic resonance imaging (MRI) which are currently the most widely used techniques and have largely replaced other modalities. CT scanning has an excellent role in the evaluation of bone and air space anatomy and disorders. Because CT scans are more accurate in identifying many soft tissue 
abnormalities and are much less prone to artifacts, CT has the advantage of producing images with higher contrast and a better spatial resolution.[13]This represent the status of the structure of the temporal bone represents a major advance in delineating pathology prior to surgical treatments.[14]

Sudan is a country in Africa. To the best of our knowledge, there are no previous studies of CSOM was done in Sudan, however a recent hospital-based case-control studies had reported results in children with CSOM in Khartoum-Sudan. [15, 16]

The proposes of this highlighting study are to provide an overview of current knowledge and scientific basis about CSOM in Sudan as one of the developing countries as well to highlight the HRCT temporal bone findings in chronic middle ear infections with reference to its extent and complications, the common sign, symptoms and the duration impact on the anatomical structures and pathological changes in each part and for both sides. Since the high index of cases referred to CT scanning, it will ensure rapid diagnosis and treatment and considerably reduces the incidence of complications in Sudanese.

\section{MATERIALS AND METHODS}

This is a prospective, analytical study which included 114 patients with chronic suppurative otitis media. The data of this study were conducted during the period from $2014-2017$, in Khartoum state. Patients came to ENT hospital and clinically diagnosed with CSOM and refereed to Antalya Medical Centre for CT scan of the temporal bones. Patients gender, age, residence, occupation, education, socio economic status, duration of disease, signs and symptoms were recorded .The sample of this study were selected from CT temporal examination cases .Patients that have undergone previous temporal bone surgeries and traumatic patients to the temporal bone were excluded from this study. In the study sample the total of the 114 participants were from Khartoum state, $51(44.7 \%)$ were females and $63(55.3 \%)$ were males. the participant's Occupation were: 15 without job constituting (13.2\%), students were $17(14.9 \%)$, workers were 32(28.1\%) and house wives were 50(43.9\%). Participant's education was: $62(54.4 \%)$ were not educated, patients who had primary education were $36(31.6 \%)$ and secondary education were 16 and constituting (14.0\%).

\subsection{Materials: CT scanner machine:}

GE 8 slice MDCT scan .Scanning parameters: 120-140 kV, 200 -220 mAs. X-ray tube specification: focal spot $0.6 \mathrm{~mm} * 0.6 \mathrm{~mm}$ and anode heat dissipation $400 \mathrm{kuH} / \mathrm{min}$, anode heat storage capacity 4.0 MHU. Gantry specification :Rotation speed $360^{\circ}$ in $0.30,1,1.5$ second ,tilt $+/-30^{\circ}$ and aperture $70 \mathrm{~cm}$ .Detector specification :Scan type eight (option), spiral or axial, slice thickness 0.5,1.0,1.5, 3.0,5.0and $10 \mathrm{~mm}$, scan mode 0.50:1 /1.5:1.Algorithm (option)standard, soft tissue ,bone and edge enhancement, matrix $512 * 512$ and $20 \mathrm{~cm}$ field of view.

\subsection{Technique and protocol:}

Scan to evaluate the organ of hearing and balance was obtained. Thin slices without overlapping were used to ensure optimal resolution, the whole skull was not imaged, and just the required part of the temporal bone was included. The two temporal bones images are magnified and imaged separately .This to make possible differentiation between small structures like the ossicles, cochlea and semicircular canals. CT scans were performed including protocol of axial images from the area of temporal bone with patient in supine position, head first. Reconstruction used to obtain coronal views of temporal bone. No preparation for patient who's undergone $\mathrm{CT}$ temporal bone was done.

\subsection{Image interpretation:}

For evaluation of images and to measure the CT number of middle ear contents the bone window setting from axial cuts was used .Each middle ear was identified and it's ossicles was observed and evaluated as (intact, partially eroded or totally eroded), mastoid were also been evaluated.

\subsection{Data Analysis}

The data were collected by using data sheet which included medical reports and were analyzed by using SPSS (statistical package of social science) version 16.

\section{FIGURES AND TABLES}

Table No (1) Distribution of study sample according to Participant's Age

\begin{tabular}{ccc}
\hline \hline & Frequency & Percentages $(\%)$ \\
\hline \hline$<10$ & 13 & 11.4 \\
$11-20$ & 11 & 9.6 \\
$21-30$ & 17 & 14.9 \\
$31-40$ & 13 & 11.4
\end{tabular}


Findings in CSOM: Our Experience in Sudanese Population-A CT based Study

\begin{tabular}{ccc}
\hline $41-50$ & 28 & 24.6 \\
$51-60$ & 20 & 17.5 \\
$>61$ & 12 & 10.5 \\
Total & 114 & $100.0(\%)$ \\
\hline \hline
\end{tabular}

Table No (2) Distribution of study sample according to Participant's Socioeconomic status

\begin{tabular}{ccc}
\hline \hline & Frequency & Percentages $(\%)$ \\
\hline \hline Poor & 4 & 3.5 \\
Medium & 110 & 96.5 \\
Total & 114 & $100.0(\%)$ \\
\hline \hline
\end{tabular}

Table No (3) Distribution of study sample according to Participant's Sign and symptoms

\begin{tabular}{ccc}
\hline \hline & Frequency & Percentages $(\%)$ \\
\hline \hline Otolegia & 69 & 60.5 \\
Otorroea & 113 & 99.1 \\
Headache & 53 & 46.5 \\
Total & 114 & $100.0(\%)$ \\
\hline \hline
\end{tabular}

Table No (4) Descriptive Statistics of CT number (Hounsfield) measured for Participant's middle ears affected by CSOM

\begin{tabular}{|c|c|c|c|c|c|}
\hline \multicolumn{7}{|c|}{ Descriptive Statistics } \\
\hline & $\mathrm{N}$ & $\begin{array}{c}\text { Min } \\
(\mathrm{HU})\end{array}$ & $\begin{array}{c}\text { Max } \\
(\mathrm{HU})\end{array}$ & $\begin{array}{c}\text { Mean } \\
(\mathrm{HU})\end{array}$ & Std. V \\
\hline CT number of right middle ear & 114 & -200.00 & 1066.00 & 81.07 & 153.14 \\
\hline CT Number of left middle ear & 37 & -196 & 190 & 55.46 & 66.87 \\
\hline
\end{tabular}

Table No (5) Temporal bone CT findings of the Participant's middle ear

\begin{tabular}{|c|c|c|c|c|}
\hline & \multicolumn{2}{|c|}{ Right middle ear } & \multicolumn{2}{c|}{ Left middle ear } \\
\hline & Frequency & Percent (\%) & Frequency & Percentages (\%) \\
\hline Normal & 36 & 31.6 & 40 & 35.1 \\
\hline Total opacification & 6 & 5.3 & 6 & 5.3 \\
\hline Partial opacification & 41 & 36.0 & 33 & 28.9 \\
\hline Sclerotic & 2 & 1.8 & 4 & 3.5 \\
\hline Granulation & 3 & 2.6 & 5 & 4.4 \\
\hline Soft tissue density & 15 & 13.2 & 16 & 14.0 \\
\hline Fluid density & 3 & 2.6 & 3 & 2.6 \\
\hline Mucosal thickening & 8 & 7.0 & 7 & 6.1 \\
\hline Total & 114 & $100.0(\%)$ & 114 & $100.0(\%)$ \\
\hline
\end{tabular}

Table No (6) Temporal bone CT Findings of the Participant's Ossicles

\begin{tabular}{|c|c|c|c|c|}
\hline & \multicolumn{2}{|c|}{ Right Ossicles } & \multicolumn{2}{c|}{ Left Ossicles } \\
\hline & Frequency & Percent (\%) & Frequency & Percentages (\%) \\
\hline Intact & 98 & 86.0 & 98 & 86.0 \\
\hline Partial erosion & 10 & 8.8 & 10 & 8.8 \\
\hline Total erosion & 6 & 5.3 & 6 & 5.3 \\
\hline Total & 114 & $100.0(\%)$ & 114 & $100.0(\%)$ \\
\hline
\end{tabular}


Findings in CSOM: Our Experience in Sudanese Population-A CT based Study

Table No (7) Temporal bone CT Findings of the Participant's mastoid

\begin{tabular}{|l|c|c|c|c|}
\hline & \multicolumn{2}{|c|}{ Right mastoid } & \multicolumn{2}{c|}{ Left mastoid } \\
\hline & Frequency & Percent (\%) & Frequency & Percentages (\%) \\
\hline Normal & 37 & 32.5 & 45 & 39.5 \\
\hline Total opacification & 7 & 6.1 & 2 & 1.8 \\
\hline Partial opacification & 16 & 14.0 & 15 & 13.2 \\
\hline Sclerotic & 48 & 42.1 & 47 & 41.2 \\
\hline Soft tissue density & 3 & 2.6 & 4 & 3.5 \\
\hline Mucosal thickening & 3 & 2.6 & 1 & .9 \\
\hline \multicolumn{1}{|c|}{ Total } & 114 & $100.0(\%)$ & 114 & $100.0(\%)$ \\
\hline
\end{tabular}

Table No (8) Temporal bone CT number of the middle ear (Right and Left) correlated with patients' age

\begin{tabular}{|c|c|c|c|c|c|c|c|}
\hline \multicolumn{8}{|c|}{ Descriptive } \\
\hline & & $\mathrm{N}$ & $\begin{array}{l}\text { Mean } \\
(\mathrm{HU})\end{array}$ & Std. Deviation & $\begin{array}{l}\text { Min } \\
\text { (HU) }\end{array}$ & $\begin{array}{l}\text { Max } \\
\text { (HU) }\end{array}$ & $\mathrm{P}$-value \\
\hline \multirow{8}{*}{$\begin{array}{l}\text { CT number of } \\
\text { the right middle } \\
\text { ear }\end{array}$} & $<10$ & 13 & 59.30 & 20.05 & 40.00 & 90.00 & \multirow{7}{*}{.029} \\
\hline & $11-20$ & 11 & 101.18 & 137.97 & 40.00 & 515.00 & \\
\hline & $21-30$ & 17 & 55.05 & 34.50 & -55.00 & 99.00 & \\
\hline & $31-40$ & 13 & 73.61 & 29.79 & 45.00 & 158.00 & \\
\hline & $41-50$ & 27 & 37.55 & 53.09 & -155.00 & 95.00 & \\
\hline & $51-60$ & 20 & 84.00 & 152.64 & -200.00 & 655.00 & \\
\hline & $>61$ & 12 & 224.16 & 377.29 & 45.00 & 1066.00 & \\
\hline & Total & 113 & 81.07 & 153.14 & -200.00 & 1066.00 & \\
\hline \multirow{8}{*}{$\begin{array}{l}\text { CT number of } \\
\text { the left middle } \\
\text { ear }\end{array}$} & $<10$ & 5 & 52.80 & 19.02 & 40 & 85 & \multirow{8}{*}{.809} \\
\hline & $11-20$ & 3 & 46.67 & 5.77 & 40 & 50 & \\
\hline & $21-30$ & 6 & 59.00 & 17.88 & 40 & 85 & \\
\hline & $31-40$ & 6 & 83.33 & 35.02 & 50 & 150 & \\
\hline & $41-50$ & 8 & 38.63 & 85.94 & -150 & 155 & \\
\hline & $51-60$ & 6 & 34.00 & 119.74 & -196 & 154 & \\
\hline & $>61$ & 3 & 93.67 & 83.42 & 45 & 190 & \\
\hline & Total & 37 & 55.46 & 66.87 & -196 & 190 & \\
\hline
\end{tabular}

Table No (9) Temporal bone HRCT findings for the middle ear (Right and Left) correlated with duration of disease (CSOM)

\begin{tabular}{|c|c|c|c|c|c|c|c|c|c|}
\hline \multicolumn{10}{|c|}{ Descriptive } \\
\hline \multirow[t]{2}{*}{$\begin{array}{c}\text { Duration of } \\
\text { CSOM }\end{array}$} & \multirow[t]{2}{*}{$\begin{array}{l}\text { HRCT Findings in the } \\
\text { Middle Ear }\end{array}$} & \multirow[t]{2}{*}{$\mathrm{N}$} & \multirow[t]{2}{*}{ Mean } & \multirow[t]{2}{*}{ Std. V } & \multirow[t]{2}{*}{ Std. Error } & \multicolumn{2}{|c|}{$\begin{array}{l}95 \% \text { Confidence Interval } \\
\text { for Mean }\end{array}$} & \multirow[t]{2}{*}{ Min } & \multirow[t]{2}{*}{ Max } \\
\hline & & & & & & $\begin{array}{l}\text { Lower } \\
\text { Bound }\end{array}$ & $\begin{array}{l}\text { Upper } \\
\text { Bound }\end{array}$ & & \\
\hline \multirow{9}{*}{$\begin{array}{c}\text { RT Middle Ear } \\
\text { F=5.802 } \\
\text { Sig at } 0.000\end{array}$} & Normal & 36 & 6.11 & 8.47 & 1.41 & 3.24 & 8.97 & .11 & 24.00 \\
\hline & Total opacification & 6 & 1.19 & .70 & .28 & .44 & 1.93 & .15 & 2.00 \\
\hline & Partial opacification & 41 & 2.94 & 6.08 & .95 & 1.02 & 4.8719 & .11 & 24.00 \\
\hline & Sclerotic & 2 & 25.00 & 7.07 & 5.00 & -38.53 & 88.53 & 20.0 & 30.00 \\
\hline & Granulation & 3 & 4.66 & 2.51 & 1.45 & -1.58 & 10.91 & 2.00 & 7.00 \\
\hline & Soft tissue density & 15 & 12.73 & 5.66 & 1.46 & 9.59 & 15.86 & 2.00 & 24.00 \\
\hline & Fluid density & 3 & .66 & .20 & .12 & .14 & 1.18 & .50 & .90 \\
\hline & Mucosal thickening & 8 & 4.28 & 10.41 & 3.68 & -4.42 & 12.98 & .15 & 30.00 \\
\hline & Total & 114 & 5.60 & 8.03 & .75 & 4.11 & 7.09 & .11 & 30.00 \\
\hline \multirow{9}{*}{$\begin{array}{r}F=23.182 \\
\text { Sig .015 }\end{array}$} & Normal & 0 & . & . & . & . & . & . & . \\
\hline & Total opacification & 4 & 7.00 & 6.68 & 3.34 & -3.63 & 17.63 & 1 & 15 \\
\hline & Partial opacification & 19 & 1.99 & 4.07 & .93 & .03 & 3.96 & 0 & 18 \\
\hline & Sclerotic & 1 & 5.00 &. & . & . & . & 5 & 5 \\
\hline & Granulation & 2 & 4.50 & 3.53 & 2.50 & -27.27 & 36.27 & 2 & 7 \\
\hline & Soft tissue density & 7 & 11.86 & 8.84 & 3.34 & 3.68 & 20.03 & 2 & 24 \\
\hline & Fluid density & 2 & .70 & .283 & .200 & -1.84 & 3.24 & 1 & 1 \\
\hline & Mucosal thickening & 2 & .63 & .530 & .37 & -4.14 & 5.39 & 0 & 1 \\
\hline & Total & 37 & 4.47 & 6.45 & 1.06 & 2.32 & 6.62 & 0 & 24 \\
\hline
\end{tabular}




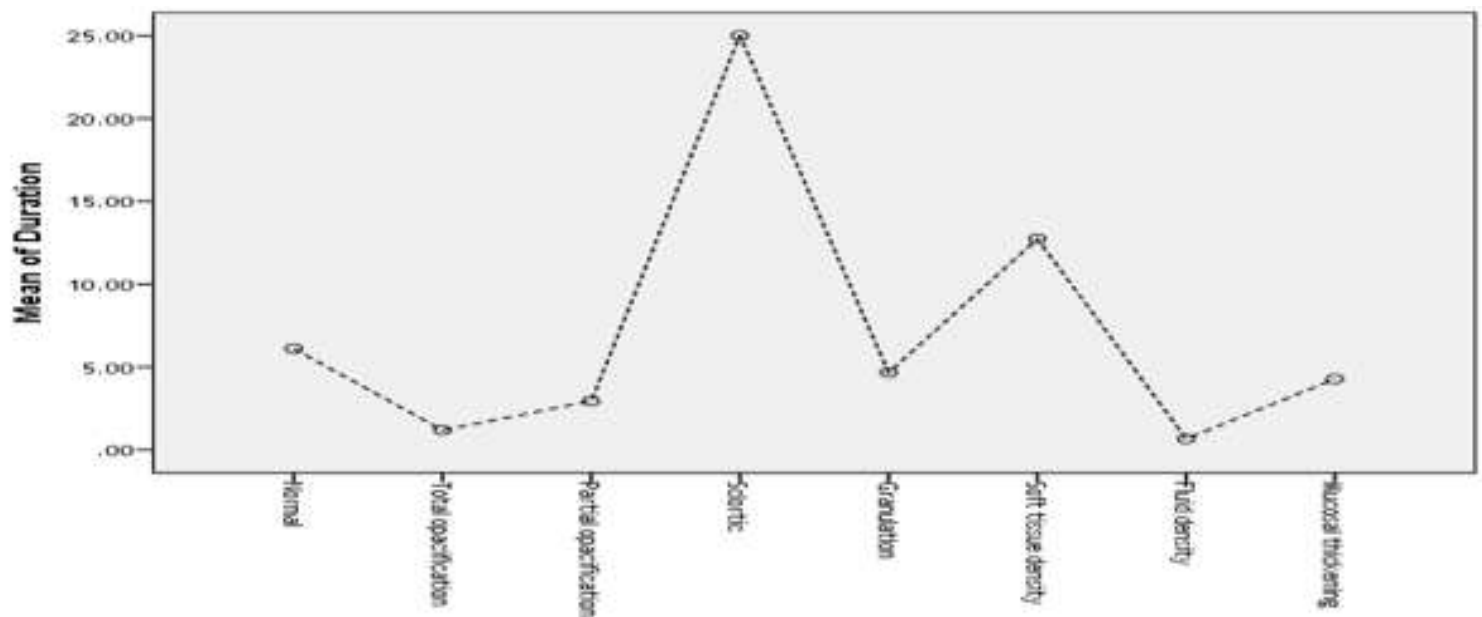

[A]

Right Middle Ear

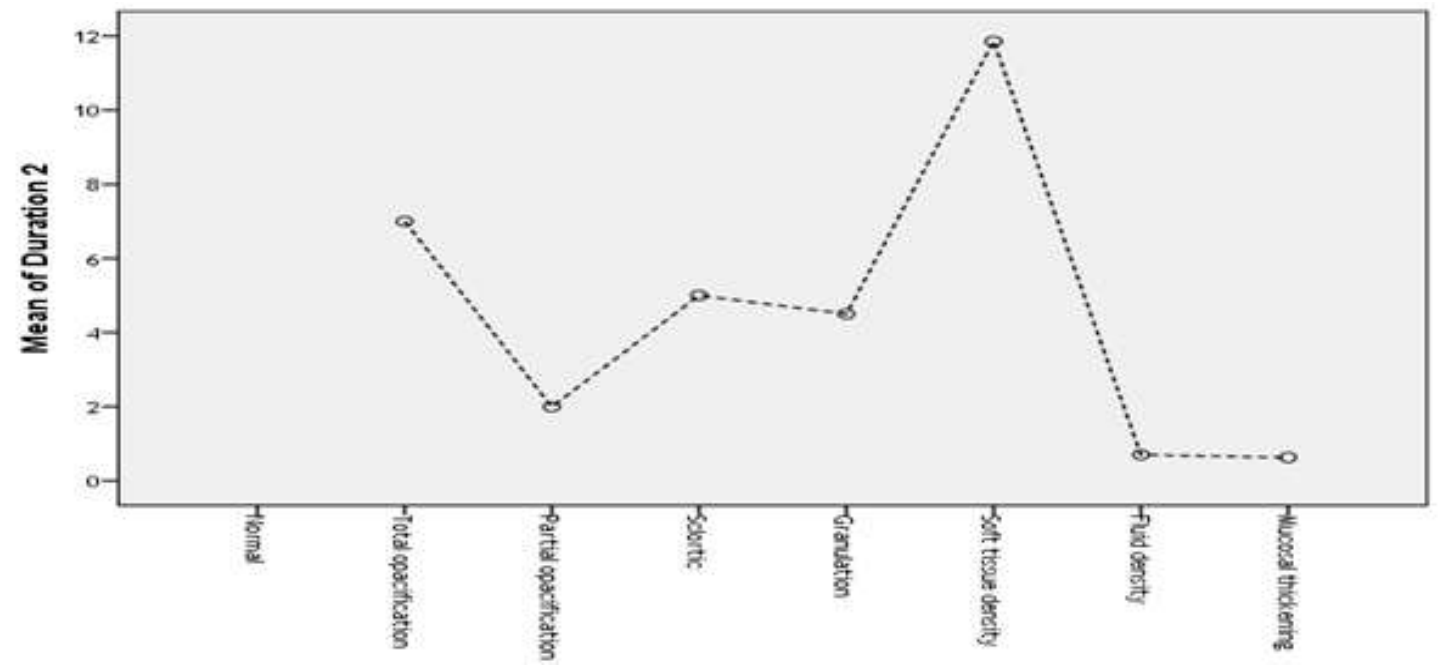

Left Middle Ear

[B]

Figure (1)A,B .[A]: shows the mean plot of the findings in the right middle ear and the duration of CSOM, sclerotic changes is the commonest result of increasing duration. [B] shows the findings in the left middle ear and the duration of CSOM,it shows that the soft tissue density increased as the duration increased.\{ mean of duration2 stands for duration of CSOM in the left side \}

Table No (10) Temporal bone HRCT Findings for the Ossicles (Right and Left) correlated with duration of (CSOM)

\begin{tabular}{|c|c|c|c|c|c|c|c|c|c|}
\hline \multicolumn{10}{|c|}{ Descriptive } \\
\hline \multirow[b]{2}{*}{$\begin{array}{l}\text { Duration } \\
\text { of CSOM }\end{array}$} & \multirow{2}{*}{$\begin{array}{l}\text { HRCT Findings in the } \\
\text { Ossicles }\end{array}$} & \multirow[b]{2}{*}{$\mathrm{N}$} & \multirow{2}{*}{ Mean } & \multirow{2}{*}{ Std. V } & \multirow{2}{*}{$\begin{array}{l}\text { Std. } \\
\text { Error }\end{array}$} & \multicolumn{2}{|c|}{$\begin{array}{l}\text { 95\% Confidence Interval for } \\
\text { Mean }\end{array}$} & \multirow[b]{2}{*}{ Min } & \multirow{2}{*}{$\operatorname{Max}$} \\
\hline & & & & & & $\begin{array}{l}\text { Lower } \\
\text { Bound }\end{array}$ & $\begin{array}{l}\text { Upper } \\
\text { Bound }\end{array}$ & & \\
\hline \multirow{4}{*}{$\begin{array}{c}\text { Right Ossicle } \\
\quad F=16.95 \\
\text { Sig } .000\end{array}$} & Intact & 98 & 4.24 & 7.01 & .70 & 2.84 & 5.65 & .11 & 30.00 \\
\hline & Partial erosion & 10 & 10.01 & 5.78 & 1.82 & 5.87 & 14.15 & .15 & 16.00 \\
\hline & Total erosion & 6 & 20.50 & 10.07 & 4.11 & 9.92 & 31.07 & 1.00 & 30.00 \\
\hline & Total & 114 & 5.60 & 8.03 & .75 & 4.11 & 7.09 & .11 & 30.00 \\
\hline \multirow{4}{*}{$\begin{array}{l}\text { Left Ossicle } \\
\mathrm{F}=3.673 \\
\text { Sig } .036\end{array}$} & Intact & 33 & 3.56 & 5.98 & 1.04 & 1.44 & 5.68 & 0 & 24 \\
\hline & Partial erosion & 3 & 11.00 & 6.55 & 3.78 & -5.29 & 27.29 & 5 & 18 \\
\hline & Total erosion & 1 & 15.00 &. &. &. &. & 15 & 15 \\
\hline & Total & 37 & 4.47 & 6.45 & 1.060 & 2.32 & 6.62 & 0 & 24 \\
\hline
\end{tabular}




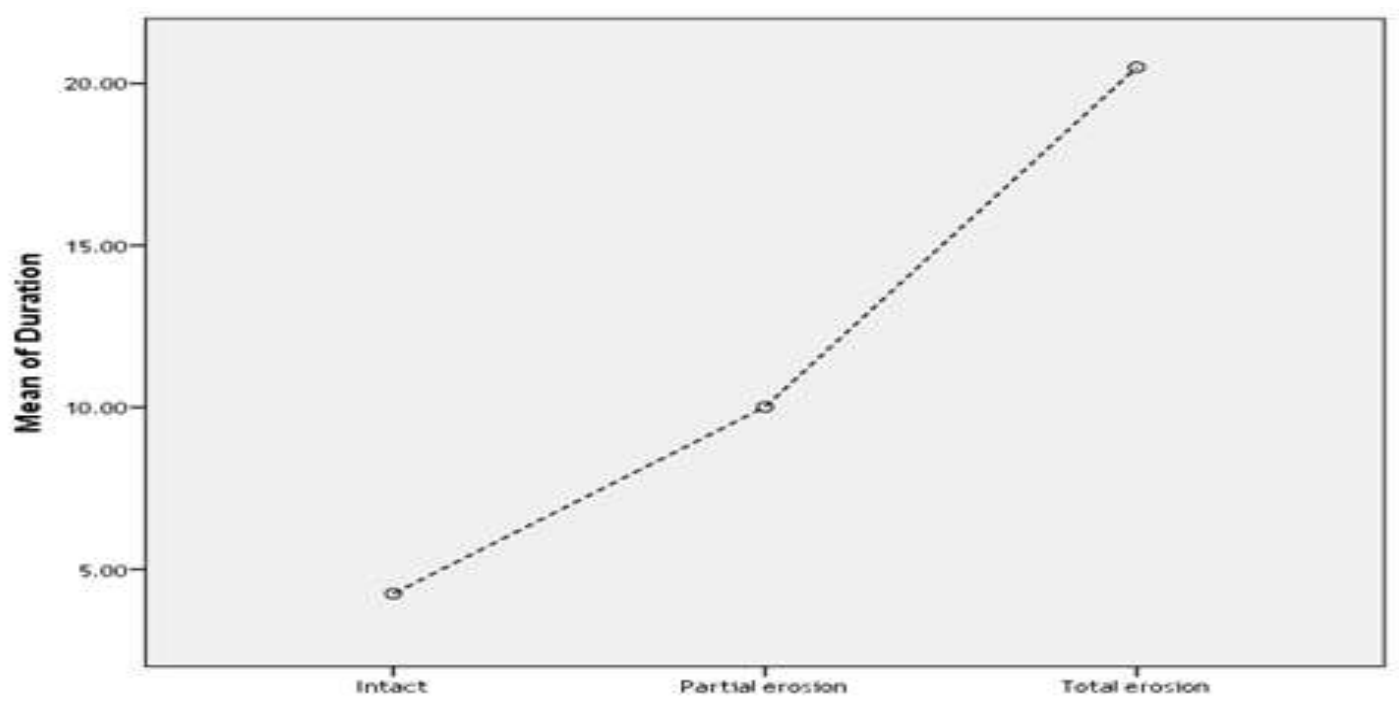

RT Ossicle

[A]

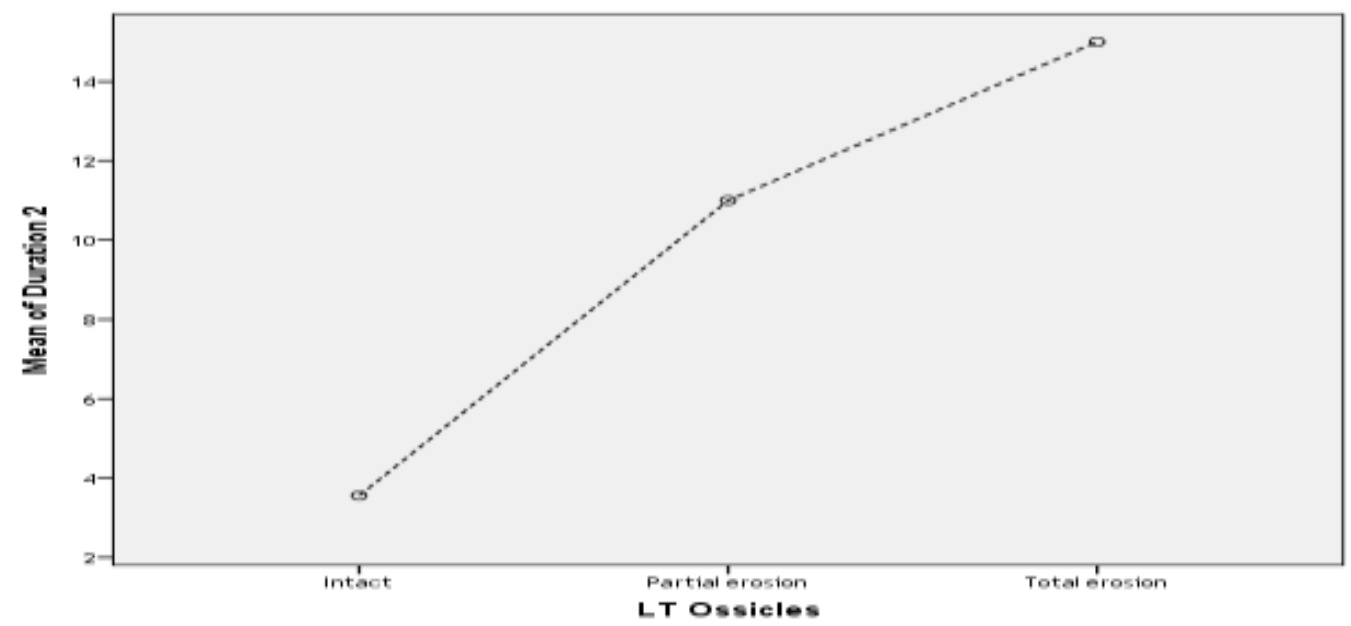

[B]

Figure (2)A,B. [A] shows the mean plot of the findings in the right(RT) ossicle and the duration of CSOM , .[B] the left (LT) ossicle and the duration of CSOM. Partial erosion and complete erosion were detected in both right and left ossicle in the advanced period of disease, where the ossicle still intact in the early stage. .\{ mean of duration 2 stands for duration of CSOM in the left side

Table No (11) Temporal bone HRCT Findings for the mastoid (Right and Left) correlated with duration of (CSOM)

\begin{tabular}{|c|c|c|c|c|c|c|c|c|c|}
\hline \multicolumn{10}{|c|}{ Descriptive } \\
\hline \multirow{2}{*}{ Duration of CSOM } & \multirow[t]{2}{*}{ HRCT Findings in the mastoid } & \multirow{2}{*}{$\mathrm{N}$} & \multirow{2}{*}{ Mean } & \multirow{2}{*}{ Std. V } & \multirow{2}{*}{$\begin{array}{l}\text { Std. } \\
\text { Error }\end{array}$} & \multicolumn{2}{|c|}{$\begin{array}{l}\text { 95\% Confidence Interval for } \\
\text { Mean }\end{array}$} & \multirow{2}{*}{ Min } & \multirow{2}{*}{ Max } \\
\hline & & & & & & $\begin{array}{l}\text { Lower } \\
\text { Bound }\end{array}$ & Upper Bound & & \\
\hline \multirow{6}{*}{$\begin{array}{c}\text { Right mastoid } \\
\mathrm{F}=2.06 \mathrm{Sig}=0.075\end{array}$} & Normal & 37 & 5.56 & 7.79 & 1.28 & 2.96 & 8.16 & .11 & 24.0 \\
\hline & Total opacification & 7 & 4.19 & 5.89 & 2.22 & -1.25 & 9.63 & .15 & 15.0 \\
\hline & Partial opacification & 16 & 5.18 & 7.52 & 1.88 & 1.17 & 9.19 & .11 & 24.0 \\
\hline & Sclerotic & 48 & 5.47 & 8.46 & 1.22 & 3.02 & 7.93 & .11 & 30.0 \\
\hline & Soft tissue density & 3 & 19.00 & 4.58 & 2.64 & 7.61 & 30.38 & 15.0 & 24.0 \\
\hline & Total & 114 & 5.60 & 8.03 & .75 & 4.11 & 7.09 & .11 & 30.0 \\
\hline \multirow{7}{*}{$\begin{array}{c}\text { Left mastoid } \\
\mathrm{F}=2.83 \mathrm{Sig}=0.041\end{array}$} & Normal & 4 & 1.76 & 2.19 & 1.1 & -1.72 & 5.25 & 0 & 5 \\
\hline & Total opacification & 1 & 15.00 & . &. & . & . & 15 & 15 \\
\hline & Partial opacification & 5 & .80 & .38 & .17 & .32 & 1.29 & 0 & 1 \\
\hline & Sclerotic & 26 & 4.67 & 6.60 & 1.29 & 2.00 & 7.34 & 0 & 24 \\
\hline & Soft tissue density & 1 & 18.00 & . & . & . & . & 18 & 18 \\
\hline & Mucosal thickening & 0 & . &. & . & . &. & . & . \\
\hline & Total & 37 & 4.47 & 6.450 & 1.06 & 2.32 & 6.62 & 0 & 24 \\
\hline
\end{tabular}




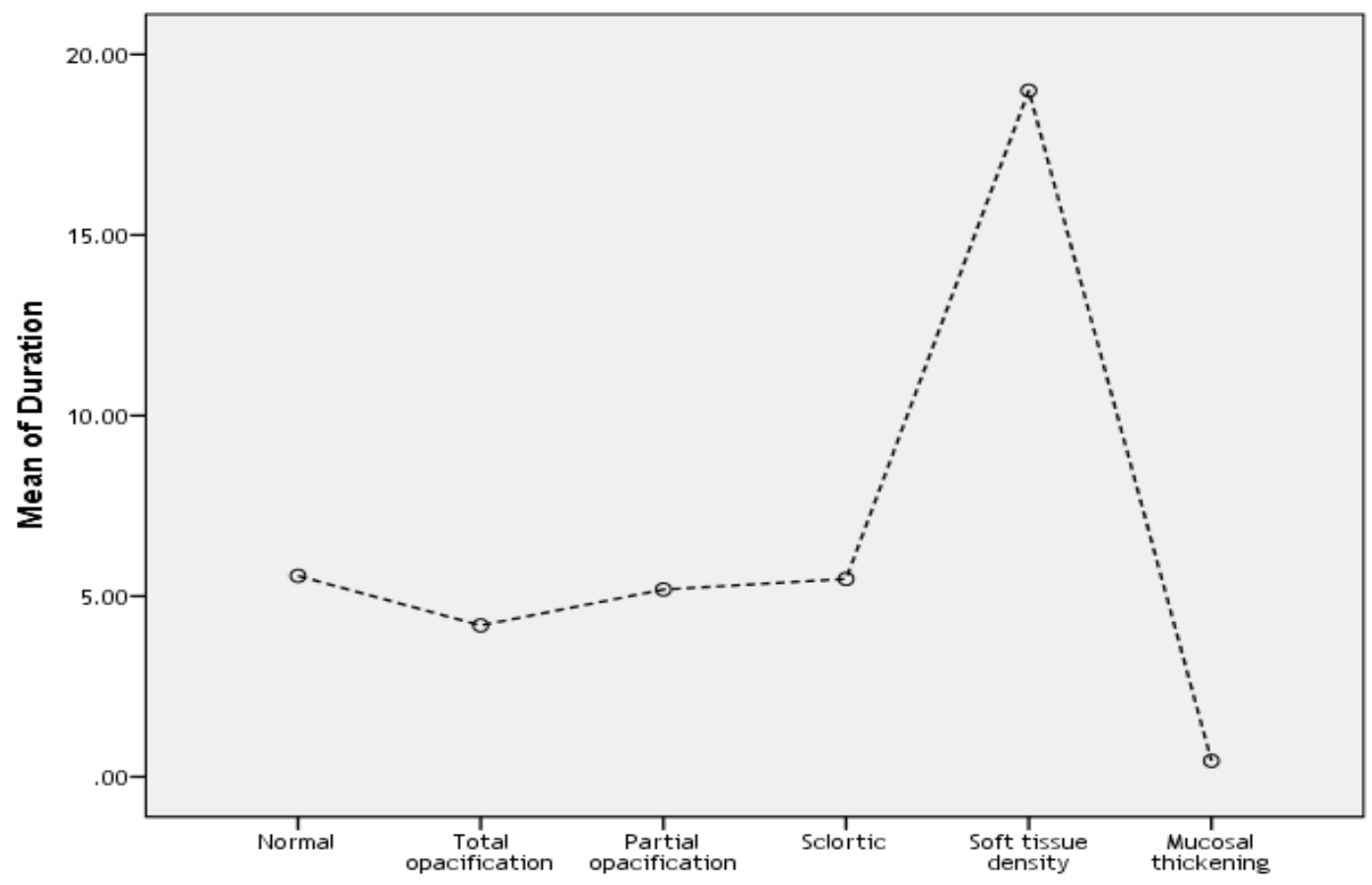

Rt mastoid

[A]

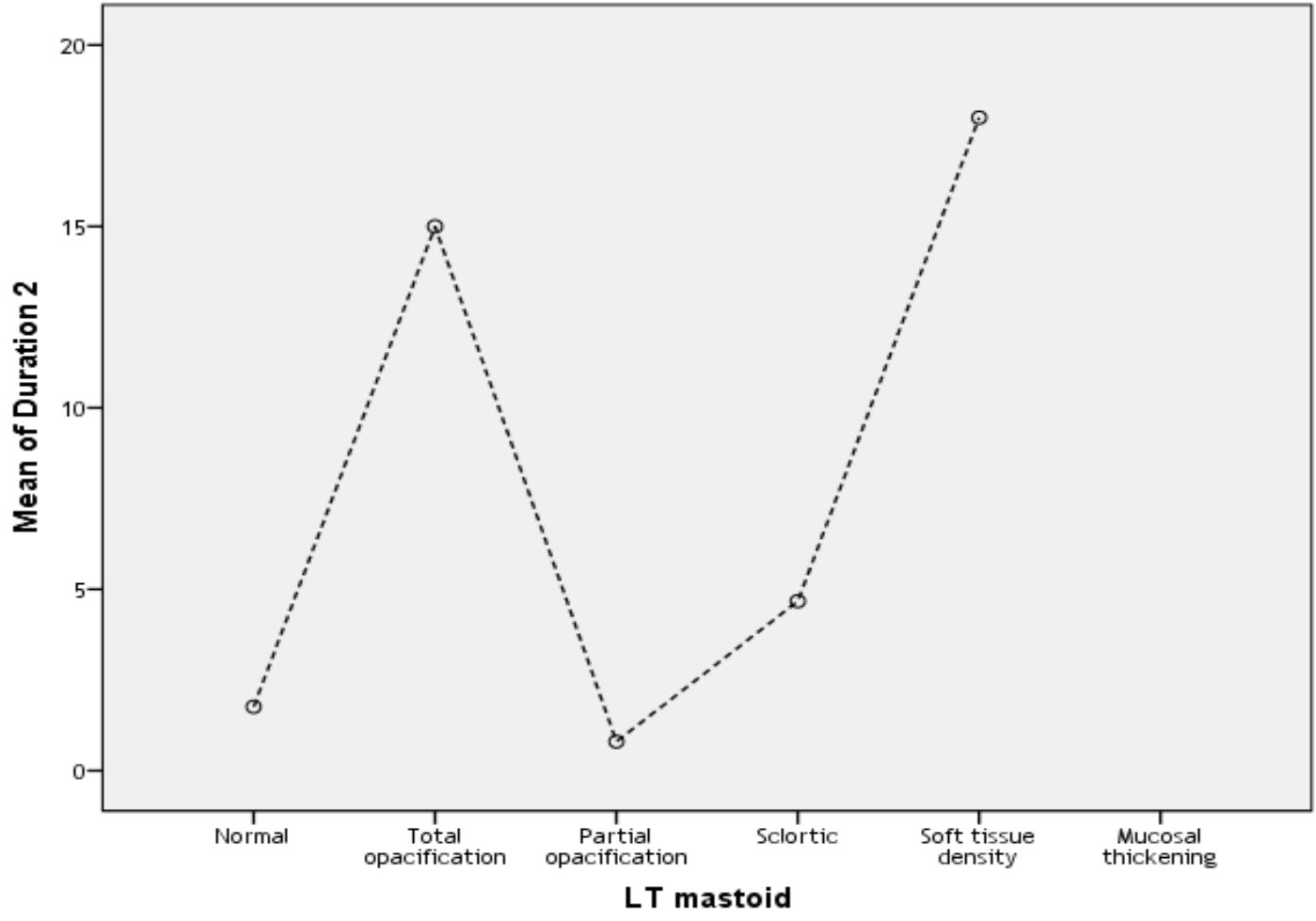

$[B]$

Figure (3)A,B. [ A] shows the mean plot of the findings in the right (RT) mastoid and the duration of CSOM.[B] the left ( LT) mastoid and the duration of CSOM.The changes of soft tissues density was the commonest findings detected in both right and left mastoid in HRCT for temporal bone scanning. \{ mean of duration2 stands for duration of CSOM in the left side\} 
Findings in CSOM: Our Experience in Sudanese Population-A CT based Study

Table No (12) The Socioeconomic status correlated with duration of (CSOM)

\begin{tabular}{|c|c|c|c|c|c|c|c|c|c|}
\hline \multicolumn{10}{|c|}{ Descriptive } \\
\hline \multirow{2}{*}{$\begin{array}{c}\text { Duration of } \\
\text { CSOM }\end{array}$} & \multirow{2}{*}{$\begin{array}{c}\text { Socioeconomic } \\
\text { Status }\end{array}$} & \multirow{2}{*}{$\mathrm{N}$} & \multirow{2}{*}{ Mean } & \multirow{2}{*}{ Std. V } & \multirow{2}{*}{$\begin{array}{l}\text { Std. } \\
\text { Error }\end{array}$} & \multicolumn{2}{|c|}{$\begin{array}{l}\text { 95\% Confidence Interval } \\
\text { for Mean }\end{array}$} & \multirow{2}{*}{ Min } & \multirow{2}{*}{$\operatorname{Max}$} \\
\hline & & & & & & $\begin{array}{l}\text { Lower } \\
\text { Bound }\end{array}$ & $\begin{array}{l}\text { Upper } \\
\text { Bound }\end{array}$ & & \\
\hline \multirow{3}{*}{$\begin{array}{c}\text { Right Side } \\
\mathrm{F}=0.16 \\
\text { Sig .684 }\end{array}$} & Poor & 4 & 7.22 & 6.73 & 3.36 & -3.48 & 17.93 & .90 & 14.00 \\
\hline & Medium & 110 & 5.54 & 8.09 & .77 & 4.01 & 7.07 & .11 & 30.00 \\
\hline & Total & 114 & 5.60 & 8.03 & .75 & 4.11 & 7.09 & .11 & 30.00 \\
\hline \multirow{3}{*}{$\begin{array}{l}\text { Left Side } \\
F=14.85 \\
\text { Sig } .000\end{array}$} & Poor & 2 & 19.0 & 7.07 & 5.00 & -44.5 & 82.53 & 14 & 24 \\
\hline & Medium & 35 & 3.64 & 5.4 & .917 & 1.78 & 5.51 & 0 & 18 \\
\hline & Total & 37 & 4.47 & 6.45 & 1.06 & 2.32 & 6.62 & 0 & 24 \\
\hline
\end{tabular}

\section{Discussion}

This study is an attempt to characterize the HRCT imaging findings of temporal bones in CSOM diagnosed for Sudanese patients. A total number of 114 patients were studied. Of the 114 patients, the age at presentation ranged from <10years to >65years. The mean age was 39.16 years $\pm 20.3(\max =86$ years, min=1year) and the maximum numbers of patients affected in the age group of 41 to 50 years were 28 constituting (24.6\%) table (1). This age group which was affected by CSOM is similar to study bone by Paperella and Kim, 1977 [17].In this Sudanese study; CSOM was slightly more common in males (55.3\%) than females (44.7\%), similar findings highlighted by Rohit et al, 2016 in Indian population -India as one of the developing countries.[2]

CSOM is a major health problem in developing countries like Sudan despite the advances in healthcare facilities. It is one of the common diseases in ENT practice. In our country burden of the disease is too high .CSOM is more common in low socio-economic status groups tables $(2,12)$. A significant relation was found in patients with low socioeconomic status and duration of CSOM. We referred these findings in Sudanese coming to our ENT and CT departments to the overcrowding, frequent upper respiratory tract infection, unavailable health care knowledge, as the patients are of primary or uneducated groups; this was similarly found and juto stified by Bijan [18] previously.

Otorrhoea was found in $113(99.1 \%)$ of the cases, acting the most common symptom, followed by otalgia $69(60.5 \%)$, and headache that was found in $53(46.5 \%)$, table (3). These findings are consistent with the study done in India where the complication as hearing loss was also been presented in their population, we would like to highlight that the CSOM which usually presents with otorrhoea, otalgia and other symptoms causing psychological disturbance and financial burden to the society as mentioned by Bijan.[18] The mean of maximum CT numbers varies in both sides of ears, this because there are many changes were happened in ears affected with CSOM ranged between 1066.00 \pm 153.14 and 190 \pm 66.87 Hounsfield for right and left side respectively as presented in table (4) and significantly affected with the patients' age, table (8).

The justification to have changes in CT number; is that the Otitis media presents in acute phase, do reversible mucosal and bony pathological changes, which continues to a late chronic phase with intractable mucoperiosteal disease. [19].The recurrent occurrence of otorrhoea and different signs and symptoms with long duration of disease extended to years lead to mucosal changes which are characterized by osteoneogenesis, bony erosions, and osteitis that include the temporal bone, ossicles and mastoid that lead to destruction, total or partial opacification, sclerotic changes, presence of soft tissue density and mucosal thickening which is probably lead to change the CT (HU). Similar studies had mentioned that tympanic perforation may also been found due to long stage of CSOM, contributing to the hearing loss [20,21].However our sample didn't affected with such complications .Changes in right and left middle ear, ossicles and mastoid were presented in tables $(5,6,7)$

Duration of CSOM and the changes detected in right and left middle ear were significantly presented in table (9) and figure (1), (F=5.802, Sig at 0.000), and (F=23.182,Sig at .015) respectively .Sclerotic changes was found to be the commonest result due to increasing duration in the right middle ear, where the soft tissue density increased as the duration increased significantly in the left middle ear .Right and left Ossicles were also affected significantly with increasing of CSOM duration $(\mathrm{F}=16.959$, Sig at 0.000$)$ and $(\mathrm{F}=3.673, \mathrm{Sig}$ at 0.036$)$ .Partial and complete erosion were detected in both right and left ossicle in the advanced period of disease, where the ossicle still intact in the early stage ,these were noticed in table(10) and figure (2).The changes of soft tissues density was the commonest findings detected in both right and left mastoid in HRCT for temporal bone scanning. Significant changes were detected in the left mastoid (F=2.832, Sig at0.041) as seen in table (11) and figure(3).

Many findings have been found in Sudanese with long standing CSOM, on the other hand; studies have mentioned that long duration, lead to severity of the cases compared with acute otitis media [5].The importance of taking care about CSOM in children because it is likely inhibit language and development. Several studies have linked persistent and significant hearing loss from otitis media during the first two years of life with learning disabilities [6,7]. Other studies have shown no effect $[8,9]$. 


\section{CONCLUSION}

Regarding the results, the study showed that HRCT of temporal bone is useful in identifying various findings related to the location and extent of disease which are clinically obscured and is of significance in guiding the surgeon in planning the surgical approach, similarly the literature have mentioned that the ability of the high resolution computed tomogram to depict the status of the structure of the temporal bone represents a major advance in delineating pathology [22], as well, HRCT scan for temporal bone is valuable in diagnosis of soft tissue density and when the disease is restricted to anatomical structures, beyond otoscopic view.

The ability of HRCT in the evaluation of the acquired changes based on the detection of soft tissue mass and areas of bone destruction and measuring the CT(Hounsfield) make it of an acknowledged and excellent results in the detection of changes and reduce complications in Sudanese.

\section{Acknowledgements}

We sincerely thank the participants without whom the study would not have been feasible. The Sudan University of Science and Technology, College of Medical Radiological Science and Radiology Departments in which the study was obtained, Khartoum-Sudan are thankfully acknowledged.

\section{REFERENCES}

[1]. World Health Organization. Chronic suppurative otitis media; burden of illness and management options. Geneva, Switzerland. World Health Organization. 2004; 2-83. http://www.who.int/pbd/deafness/activities/hearing_care/otitis_media.pdf

[2]. Rohit Vallabhaneni, Srinivasa Babu C.R. (2016), HRCT Temporal Bone Findings in CSOM: Our Experience in Rural Population of South India IOSR Journal of Dental and Medical Sciences. Volume 15, Issue 1 Ver. II PP 49-53

[3]. Browning GG, Gatehouse S. (1989)Hearing in chronic suppurative otitis media. Ann Otol Rhinol Laryngol.,98: 245-250.

[4]. Chao WY, Wu CC. (1994)Hearing impairment in chronic otitis media with cholesteatoma. JFormos Med Assoc., 93 (10): 866869.

[5]. Nozza RJ. (1990)Audiologic considerations: beyond the threshold. Ann Otol Rhinol Laryngol.,99 (Suppl.): $34-36$.

[6]. Teele DW, Klein JO, Chase C, Menyuk P, Rossner B, (1990)The Greater Boston Otitis MediaStudy Group. Otitis media in infancy and intellectual ability, school achievement, speech and language at age 7 years. J Infect Dis.,162: 658-694.

[7]. Teele DW, Klein JO, Rosner BA, (1984) The Greater Boston Otitis Media Study Group. Otitis media with effusion during the first three years of life and development of speech and language. Pediatrics, 74 (2): 282-295.

[8]. Fishler RS, Todd NW, Feldman CM. (1985).Otitis media and language performance in a cohort of Apache Indian children. Am J Dis Child.139 (4): 355-360.

[9]. Hubbard TW, Paradise JL,McWilliams BJ, Elster BA, Taylor FH. (1985).Consequences of unremitting middle-ear disease in early life: otologic, audiologic, and developmental findings in children with cleft palate. N Eng J Med., , 312: 1529-1534.

[10]. Smith AW, Hatcher J, Mackenzie, IJ, Thompson S, Bal J, Mac P, Okoth-Olende C,Oburra H, Wanjohi Z. (1996 )Randomised control of chronic suppurative otitis media in Kenyan schoolchildren. Lancet, 348: 1128-1133.

[11]. World Health Organization. Prevention of hearing impairment from chronic otitis media, Report of a WHO/CIBA Foundation Workshop, held at The CIBA Foundation. World Health Organization, London, U.K. 1996; 19-21. http://www.who.int/pbd/deafness/en/ chronic_otitis_media.pdf .

[12]. Salem Muftah, Ian Mackenzie, Brian Faragher and Bernard Brabin (2015), Prevalence of Chronic Suppurative Otitis Media (CSOM) and Associated Hearing Impairment Among School-aged Children in Yemen Oman Medical Journal Vol. 30, No. 5: 358-365

[13]. Kangsanarak J, Fooanant S, Ruckphaopunt K, Navacharoen N, Teotrakul S (1993) Extracranial and intracranial complications of suppurative otitis media: report of 102 cases. J Laryngol Otol 107:999-1004

[14]. Buckingham RA, Valvassor GE; Tomographic and surgical pathology of cholesteatoma. Archives of Otolaryngology, 1970; 91(5): 464- 469.

[15]. Eatmad Abd Allah Babeker and Wafa Ibrahim Elhag . (2016) Bacterial pathogens associated with otitis media among patients attending Khartoum state hospitals journal of science / vol 6 / issue 1 / 49-53.

[16]. Enas M Abd Algalil, , Abu Sudian HA Elhaj, Ilham M Omer, (2017) Frequency of ear, nose and throat diseases in Ahmed Gasim Paediatric Teaching Hospital- Khartoum North Sudan Med J;53(1):19-24

[17]. Paparella MM, Kim CS. (1977)Mastoidectomy update. Laryngoscope;87:88.

[18]. Bijan Basak, Ganesh Chandra Gayen, Munmun Das (Sarkar), Gautam Dhar, Ritam Ray, Atanu Kumar Das (2014), Demographic profile of CSOM in a rural tertiary care hospital ,IOSR Journal Of Pharmacy (e)-ISSN: 2250-3013, ( $p$ )-ISSN: 2319-4219 www.iosrphr.org Volume 4, Issue 6 PP. 43-46

[19]. Meyerhoff W. (1988)Pathology of chronic suppurative otitis media. Ann Otol Rhinol Laryngol Head and Neck Surg., 97 (Suppl. 130): 21-24.

[20]. Paparella MM, Schumrick DA. Otolaryngology. 3rd edition. Philadelphia, WB Saunders Co., 1991.

[21]. Cummings C. Otolaryngology-Head and Neck Surgery. St Louis,Mosby-Year Book, $2^{\text {nd }}$ ed., 1993,Vol. 4: 2830.

[22]. Jayandra Gyanu, Amit Modwal, Rakesh Saboo, Gaurav Saxena, Gaurav Sapra . (2014)A Study of the Correlation of the Clinical Feature, Radiological Evaluation and Operative Finding in CSOM with Cholesteatoma. Sch. J. App. Med. Sci.,; 2(6F):32593269 . 